\title{
TUHAN DALAM PERSPEKTIF AL-QURAN
}

\author{
lim Fahimah \\ Fahimah_iim@yahoo.co.id \\ Dosen Pascasarjana IAIN Bengkulu
}

\begin{abstract}
The word "God" is generally used to refer to an eternal and supernatural substance. For a family of divine religions, the word God itself usually refers to God, who is believed to be the most perfect, the owner of heaven and earth worshiped by humans. In Arabic, this word is equivalent to the word Rabb. According to Ibn Athir, God and Lord in a language mean the owner, ruler, regulator, coach, administrator and giver of favor. The word Allah alone in the Qur'an is called 2697 times, while the word Rabb (Rabb, Rabbi, Rabbuna, Rabbukum, and Rabbuhu) is 839 times, while the word Ilah (Ilahuna Ilahukum Alihatun, Alihati, Alihihatuna Alihatukum) exists 147 times. Not to mention a kind of Wahid's words, Sunday, or a sentence which denies there are allies for either in deeds or authority to establish laws or reasonableness of worship to other than Him or other explanations which all lead to an explanation of tawhid. God and fitrah are two words that cannot be separated because fitrah is the origin of the incident, back to the origin, even said it also means God, the human being there is an element of God so wherever he is he cannot be separated from God.

Keyword: God, the Qur'anic perspective.
\end{abstract}

Abstrak: Kata "Tuhan" pada umumnya dipakai untuk merujuk kepada suatu zat abadi dan supranatural. Bagi rumpun agama samawi, kata Tuhan sendiri biasanya mengacu pada Allah, yang diyakini sebagai zat yang Maha sempurna, pemilik langit dan bumi yang disembah manusia. Dalam bahasa Arab kata ini sepadan dengan kata rabb. Menurut Ibnu Atsir, Tuhan dan tuan secara bahasa diartikan pemilik, penguasa, pengatur, pembina, pengurus dan pemberi nikmat. Kata Allah saja dalam dalam Al-Qur'an disebut 2697 kali, sedangkan kata Rabb (Rabb, Rabbi, Rabbuna, rabbukum dan Rabbuhu) sebanayak 839 kali,sedangkan kata Ilah (Ilahun, Ilahi, Ilahuna Ilahukum Alihatun, Alihati, Alihihatuna Alihatukum) ada 147 kali. Belum lagi semacam kata Wahid, Ahad, atau kalimat yang menafikan ada sekutu baginyna baik dalam perbuatan atau wewenang menetapkan hukum atau kewajaran beribadah kepada selain-Nya atau penjelasan lain yang semuanya mengarah penjelasan tentang tauhid. Tuhan dan fitrah adalah dua kata yang tidak bisa dipisahkan karena fitrah itu adalah asal kejadian, kembali ke asal, bahkan dikatakan juga artinya Tuhan, manusia itu pada dasarnya memang ada unsur Tuhan maka di mana pun dia berada ia tidak akan bisa lepas dengan Allah.

Kata kunci: Tuhan, Persfektif alquran.

\section{Pendahuluan}

Pembahasan tentang Tuhan dan Fitrah manusia itu sangat menarik, karena membicarakan sesuatu yang dicintainya tidak akan pernah bosan dan habis untuk dibahas, hanya saja batasan batasan tentang pembahasan ini perlu digali dan diluruskan sehingga tidak ada kesalah pahaman dalam memahami dan memposisikan Tuhan dan fitrah manausia sesuai dengan inormasi AlQuran dan Hadis. Selanjutnya dalam memba- 
has tentang Tuhan dalam perspektif al-Quran, dalam wawasan al-Quran yanga dikarang oleh M Quraish Shihab ada beberapa hal yang terkait yaitu : Fitrah manusia : Keyakinana tentang keesaan Allah, Tauhid adalah prinsip dasar agama samawi, Bukti-bukti kesaan Tuhan, Macammacam kesaan Tuhan. ${ }^{1}$ Agar pembahasan tidak terlalu melebar maka penulis hanya membatasi pada Term fitrah manusian : Keyakinan tentang keesaan Allah. Dalam tulisan ini tidak memuat asabab an-nuzul karena ayat-ayat yang penulis ambil setelah diteliti tidak ada asbab an-nuzulnya.

\section{Pembahasan}

\section{A. Pengertian Fitrah}

Fitrah berasal dari akar kata fathara dalam bahasa Arab yang berarti membuka atau menguak. Fitrah sendiri mempunyai makna asal kejadian, keadaan yang suci dan kembalikeasal.Dalam Islam terdapat konsep bahwa setiap orang dilahirkan dalam keadaan fitrah. Fitrah dalam hal ini berarti bayi dilahirkan dalam keadaan suci, tidak memiliki dosa apapun. Seseorang yang kembali kepada fitrahnya, mempunyai makna ia mencari kesucian dan keyakinannya yang asli, sebagaimana pada saat ia dilahirkan. ${ }^{2}$

lalu ada beberapa definisi yang menerangkan tentang masalah fitrah yaitu sebagai berikut :Menurut ibn al-Qayyim dan ibn al-Katsir, karena fatir artinya menciptakan, maka fitrah artinya keadaan yang dihasilkan dari penciptaannya itu, Menurut hadist yang diriwayatkan oleh ibnu Abbas, fitrah adalah awal mula penciptaan manusia. Sebab lafadz fitrah tidak pernah dikemukakan oleh al-Qur'an dalam konteksnya selain dengan manusia. Dalam kamus Al Munjid yaitu kamus bahasa arab terluas kata fitrah diartikan atau didefinisikan sebagai sunnah, kejadian, tabiat. ${ }^{3}$ Menurut Syahminan Zain bahwa fitrah adalah potensi laten atau suatu kekuatan yang terpendam yang ada dalam diri manusia, yang dibawanya sejak lahir dan itu semua dimiliki oleh setiap manusiaFitrah dalam Al-Quran disebutkan sebanyak 20 kali. Masing-masing ayat yang memuat term fitrah memiliki bentuk, kategori, subjek, objek, aspek dan makna tersendiri.

\section{B. Pengertian Tuhan}

Kata Tuhan dalam bahasa Indonesia adalah sesuatu yang diyakini, dipuja, dan disembah oleh manusia sebagai yang maha kuasa, maha perkasa, yang maha Esa dsb. Sedangakan kata bertuhan artinya percaya dan berbakti kepada Tuhan atau memuja sesuatu yang dianggap sebagai Tuhan. ${ }^{4}$ Sedangkan kata Tuhan dalam bahasa arab ada beberapa macam diantaranya, رب.jamaknya روبوب menjadi روباب dengan memakai alif dan lam itu artinya adalah Allah, dengan kata lain tidak bisa didefinisikan dan dimaksudkan dengan Tuhan yang lain selain Allah. Ketika kata Rabb itu tidak memakai tasydid pada huruf badengan menggunakan kata الربوبية , الربابة , atau ربوبي itu juga sama, dinisbatkan dengan kata Rabb dengan tanpa qiyas. Kata Rabb, ketika digandeng dengan kata lain sepaerti kalimat artinya pemiliknya yang berhaknya atau yang mempunyai sesuatau. ${ }^{5}$

Tuhan dipahami sebagai zat yang Mahakuasa dan asas dari suatu kepercayaan.Tidak ada kesepakatan bersama mengenai konsep ketuhanan, sehingga ada berbagai konsep ketuhanan meliputiteisme deisme panteisme dan lain-lain. Dalam pandangan teisme, Tuhan merupakan pencipta sekaligus pengatur segala kejadian di alam semesta. Menurut deisme, Tuhan merupakan pencipta alam semesta, namun tidak ikut campur dalam kejadian di alam semesta. Menurut panteisme, Tuhan merupakan alam semesta itu sendiri. Para cendekiawan menganggap ber-

\footnotetext{
${ }^{1}$ Ibid

${ }^{2}$ Fairuz Abady, Qamus al-Muhith, Birut : Dar al fikr, h. 412

${ }^{3}$ Luis ma'luf, al-munjid fi al-Lughah, Beirut : al-mathba'ah al-katsulikiyah th 1956, h. 588

${ }^{4}$ Tim Redaksi, Kamus Besar Bahasa Indonesia, Jakarta: Pusat Bahasa Departemen Pendidikan Nasional Balai Pustaka, th.2000, h. 885
} 
Iim Fahimah $\mid$ Tuhan Dalam Perspektif Al-Quran

bagai sifat-sifat Tuhan berasal dari konsep ketuhanan yang berbeda-beda. Yang paling umum, di antaranya adalah Mahatahu (mengetahui segalanya), Mahakuasa (memiliki kekuasaan tak terbatas), Mahaada (hadir di mana pun), Mahamulia (mengandung segala sifat-sifat baik yang sempurna), tak ada yang setara dengan-Nya serta bersifat kekal abadi. Penganut monoteisme percaya bahwa Tuhan hanya ada satu, serta tidak berwujud (tanpa materi), memiliki pribadi, sumber segala kewajiban moral, dan "hal terbesar yang dapat direnungkan".

Banyak filosuf abad pertengahan dan modern terkemuka yang mengembangkan argumen untuk mendukung dan membantah keberadaan Tuha. Ada banyak nama untuk menyebut Tuhan, dan nama yang berbeda-beda melekat pada gagasan kultural tentang sosok Tuhan dan sifat-sifat apa yang dimilikinya. Atenisme pada zaman Mesir Kuno, kemungkinan besar merupakan agama monoteistis tertua yang pernah tercatat dalam sejarah yang mengajarkan Tuhan sejati dan pencipta alam semesta. ${ }^{6}$

yang disebut Aten.Kalimat "Aku adalah Aku" dalam Alkitab Ibrani, dan "Tetragrammaton" digunakansebagai nama Tuhan, sedangkan Yahweh, dan Yehuwa kadangkala digunakan dalam agama Kristen sebagai hasil vokalisasi dari YHVH. Dalam bahasa Arab, nama Allah digunakan, dan karena predominansi Islam di antara para penutur bahasa Arab, maka nama Allah memiliki konotasi dengan kepercayaan dan kebudayaan Islam. Umat muslim mengenal 99 nama suci bagi Allah, sedangkan umat Yahudi biasanya menyebut Tuhan dengan gelar Elohim atau Adonai (nama yang kedua dipercaya oleh sejumlah pakar berasaldaribahasaMesirKuno, Atena).Dalam agamaHindu, Brahman biasanydianggapsebagaiTuhan monistis.Agamaagamal ainnyamemilikipanggilanuntukTuhan,diantara nya:Bahaagama Baha'i, Waheguru dalam Sikhisme, dan AhuraMazda dalam Zoroastrianism. ${ }^{7}$
C. Ayat Ayat Tentangfitrah Manusia : Keyakinan Tentang Keesaan Allah

Maka hadapkanlah wajahmu dengan Lurus kepada agama Allah; (tetaplah atas) fitrah Allah yang telah menciptakan manusia menurut fitrah itu. tidak ada peubahan pada fitrah Allah. (Itulah) agama yang lurus; tetapi kebanyakan manusia tidak mengetahui ( QS.Ar-Rum, 30 :30). ${ }^{8}$

Dan (ingatlah), ketika Tuhanmu mengeluarkan keturunan anak-anak Adam dari sulbi mereka dan Allah mengambil kesaksian terhadap jiwa mereka (seraya berfirman): "Bukankah aku ini Tuhanmu?" mereka menjawab: "Betul (Engkau Tuban kami), Kami menjadi saksi." (kami lakukan yang demikian itu) agar di hari kiamat kamu tidak mengatakan: "Sesungguhnya Kami (Bani Adam) adalah orang-orang yang lengah terhadap ini (keesaan Tuhan),,( QS. Al-a'raf: 172)

Sesungguhnya orang-orang yang mengatakan: "Tuhan Kami ialah Allah" kemudian mereka meneguhkan pendirian mereka, Maka Malaikat akan turun kepada mereka dengan mengatakan: "Janganlah kamu takut dan janganlah merasa sedih; dan gembirakanlah mereka dengan jannah yang telah dijanjikan Allah kepadamu".( QS Fushilat, 41 :30)

(yaitu) orang-orang yang beriman dan hati mereka manjadi tenteram dengan mengingat Allah. Ingatlah, hanya dengan mengingati Allah-lah hati menjadi tenteram.( QS. Al-Ra'd : 28)

\footnotetext{
${ }^{5}$ Fairuz Abady, Qamus al-Muhith, Birut : Dar al fikr, h. 82.

${ }^{6}$ Lihat dalam bukunya Abbas Mahmud al-Aqad dalam bukunya, Allah, Kairo : Dar al-Nahdlah, th 1994

${ }^{7}$ Wikipedia

${ }^{8}$ Fitrah Allah: Maksudnya ciptaan Allah. manusia diciptakan Allah mempunyai naluri beragama Yaitu agama tauhid. kalau ada manusia tidak beragama tauhid, Maka hal itu tidaklah wajar. mereka tidak beragama tauhid itu hanyalah lantara pengaruh lingkungan.
} 
Dan mereka berkata: "Kehidupan ini tidak lain hanyalah kehidupan di dunia saja, kita mati dan kita hidup dan tidak ada yang akan membinasakan kita selain masa", dan mereka sekali-kali tidak mempunyai pengetahuan tentang itu, mereka tidak lain hanyalah menduga-duga saja. ( QS. Al-Jatsiah : 24)

Dan Kami memungkinkan Bani Israil melintasi laut, lalu mereka diikuti oleh Fir'aun dan bala tentaranya, karena hendak Menganiaya dan menindas (mereka); hingga bila Fir'aun itu telah hampir tenggelam berkatalah dia: "Saya percaya bahwa tidak ada Tuhan melainkan Tuhan yang dipercayai oleh Bani Israil, dan saya Termasuk orang-orang yang berserah diri (kepada Allah)".( QS. Yunus : 90 )

Apakah sekarang (baru kamu percaya), Padahal Sesungguhnya kamu telah durhaka sejak dahulu, dan kamu Termasuk orang-orang yang berbuat kerusakan. ( QS. Yunus : 91)

\section{Makna kosa kata}

Kata فاقم وجهك faaqim wajhaka yang dimaksud adalah perintah untuk mempertahankan dan meningkatkan upaya mempertahankan diri kepada Allah, secara sempurna karena selama ini kaum muslimin apalagi nabi Muhammad SAW. Telah menghadapkan wajah kepada tuntutan agamanya. Dari perintah di atas tersirat juga perintah untuk tidak menghiraukan gangguan kaum musyrikin yang ketika turunnya ayat ini di makkah masih banyak. Kata حنيفا hanifa biasa diartikan lurus atau cenderung kepada sesuatu. Kata ini mulanya untuk menggambarkan kaki dan kemiringannya kea rah telapak pasangannya. Yang kanan ke arah yang kiri, yang kiri kea rah yang kanan. Kelurusan itu menjadikan si pejalan tidak mencong ke kanan tidak pula ke kiri. فطرة fithrahterambil dari kata fathara berarti mencipta Sementara pakar menambahkan, fitrah adalahmencipta sesuatu pertama kali. Dengan demikian kata itu bisa juaga dipahami dalam arti asal kejadian atau bawaan sejak lahir

Al-A'rafKata اخذ akhadza artinya mengambil dan mendapatkannya, Kata ظهور هم zhuhuruhumjamak dari ظكر zhahrun artinya punggung, tapi di sini di dalam ayat ini bukan makna yang sebenarnya, tapi isti'arah dari dosa yang ditanggung oleh mereka kemudian keberatan membawanya. Kata شهدنا syahidnaberasal dari kata شهذ شهin syahida artinya menyaksikan, hadir dengan menggunakan panca indra.

Selanjutnya dalam surat fushilat, kalimat Rabbuna Allah mengandung pengkhususan sehingga ia diterjemahkan Tuhan kami hanyalah Allah. Pengkhususan itu lahir dari bentuk ma'rifah/definit pada kedua kata di atas. Kata ث tsumma mengisyaratkan kelangsungan serta kemantapan istiqamah itu dalam waktu berkepanjangan. Bukannya istiqamah tersebut baru terjadi setelah berlangsungnya waktu yang lama dari ucapan mereka. Kata استقامو istaqamu terambil dari kata قام qaamayang pada mulanya berarti lurus / tidak mencong . kata ini kemudian dipahami konsisten dan setia melaksanakan apa yang diucapkan Sufyan ats-tsaqafi bermohon kepada nabi Muhammad SAW. Untuk diberi jawan yang menyeluruh tentang Islam. Sehingga dia tidak perlu lagi bertanya kepada orang lain. Beliau menjawab singkat. “ Qul amantu billah tsumma istaqim/ ucapkanlah aku beriman kepada Allah lalu konsisten"( HR. Muslim) وابشرو بالجنة ان كنتم توعدون waabsyiru biljannati inkuntum tuaduunMaksudnya telah dijanjikan sewaktu kamu masih hidup .

Dalam surat al-Jatsiah kata الدهر ad-dahru arti asalnya adalah masa bagi alam semesta dari sejak adanya alam hingga brakhirnya alam. Dalam ayat ini artinya adalah waktu. Kata علم ilmun/ ilminartinya mengetahui sesuatu dengan sebenarnya, itu ada dua macam yaitu : 1 mengetahui suatu hal (zat ) 2. Mengetahui sesuatu akan 
adanya sesuatu tersebut atau tidak adanya sesuatu tersebut . ${ }^{12}$

جا وزنا jawazna asal kata dari jوز jawaza artinya melewati jalan, dan bolehnya sesuatu karena ia harus melewati jalan itu adalah sebuah ungkapan ten-

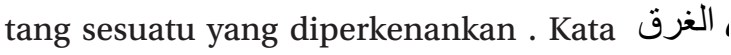
algharaquasal kata dari غرقا غرق يغرق artinya tenggelam, gagal dalam air.

\section{Munasabah Ayat}

Sebelum ayat ini dalam surat ar-Rum ayat 29 menguraikan banyak bukti serta setelah menganeka ragamkan penjelasan serta sehingga tidak ada lagi dalih yang dapat dikemukakan oleh para pembanngkang, selanjutnnya melalui ayat 30 dalam surat ar-Rum ini Allah mengarahkan kalam-Nya kepada nabi Muhammad SAW, dalam kedudukannya beliau mencamkan perintah Allah. Ayat di atas bagaikan menyatakan: " Setelah jelas bagimu - wahai Nabi- duduk persoalan, maka pertahankanlah apa yang selama ini telah engkau lakukan, hadapkanlah wajahmu serta arahkan semua perhatianmu kepada agama yang disyari'atkan Allah, yaitu agama Islam dalam keadaan lurus. Tetaplah mempertahankan fitrah Allah yang telah menciptakan manusia atasnya, yakni fitrah itu. Itulah agama yang lurus; tetapi kebanyakan manusia tidak mengetahui, yakni tidak memiliki pengetahuan yang benar. ${ }^{14}$

Menurut al biqa'i hubungan ayat 172 dalam surat al-a'raf dengan ayat sebelumnya adalah : Bani Israil diingatkan tentang perjanjian yang bersifat khusus yang telah dijalin sedemikian kuat dengan mereka. Kalau yang lalu itu bersifat khusus,sebenarnya masih ada perjanjian lain juga buat mereaka, walaupun kali ini masih bersifat umum mencakup mereka dan selain mereka dari putra putrid Adam. Kalau pada ayat yang

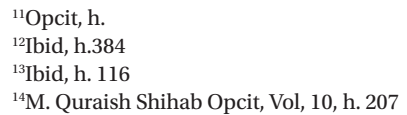

lalu mereka diingatkan ketika Allah mengangkat bukit ke atas mereka sambil memerintahkan melaksanakan apa yang tercantum dalam kitab Taurat, di sini mereka diingatkan hal lain yaitu : Dan ingatlah ketika Tuhanmu mengeluarkan dari putra -putra Adam masing-masing dari punggung, yakni sulbi orang tua mereka kemudian meletakkannya di rahim ibu-ibu mereka sampai akhirnya menjadikannya keturunan mereka manusia sempurna, dan Dia, yakni Allah mempersaksikan mereka putra-putra Adam itu atas diri mereka sendiri, yakni meminta pengakuan melalui potensi masing-masing yang dianugrahka Allah kepada mereka yakni akal. ${ }^{15}$

Dalam ayat 29 surat fushilat menjelasakan adanya teman-teman bagi pendurhaka yang menjerumuskan ke neraka yaitu manusia dan jin yang selau menggoda dan merayu, keduanya dinamai setan karena setan adalah makhluk durhaka yang mengajak kepada kedurhakaan, baik manusia maupun jin. Sementara ayat ini ayat 30 dalam surat fushilat menguraikan lawan mereka yaitu orang-orang yang beriman dan konsisten melaksanakan petunjuk imannya. ${ }^{16}$

Dalam surat fushilat dengan ayat 28 itu masih meneruskan pembicaraan yang sama dengan ayat sebelumnya ayat 27 yaitu orang-orang yang beriaman dan hati mereka menjadi tentram setelah sebelumnya bimbang dan ragu. Ketentraman itu yang bersemi di dada mereka disebabkan karena dzikrullah, yakni mengingat Allah, atau karena ayat-ayat Allah, yakni al-Quran, yang sangat mempesona kandungan dan redaksinya. ${ }^{17}$

Dalam surat ar- ra'd ayat 28 at-Thabari mengatakan sebelum ayat الذين امنوا itu ada ayat

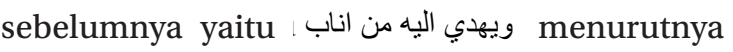

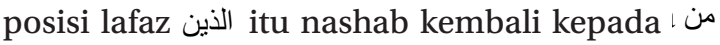
karena alladzina amanu adalah mereka yang kembali $^{18}$ Selanjutnya dalam surat al jatsiah ayat 23 mengecam kedurhakaan kaum musyrikin terhadap Allah, yakni keengganan mereka mereka mengakui kesaan-Nya, ayat 24 mengemukakan 
kedurhakaan mereka yang lain dalam ayat di atas bagaikan menyatakan : Dan disamping itu mereka berkata " Ia, yakni kehidupan ini, tidak lain kecuali kehidupan dunia kita saja,tidak ada kehidupan akhirat. Sebagian diantara kita mati sebagian diantara kita hidup, yakni lahir dan tidak ada yang membinasakan kita selain perjalanan masa yang demikian panjang. ${ }^{19}$

\section{E. Kandungan Ayat Menurut Para Mufassir}

Ayat di atas menjelaskan bahwa setiap insan yang dilahirkan ke dunia dibekali dengan fitrah untuk menginsyafi keberadaan Tuhan hingga menjalankan segala konsekuensi dari fitrah tersebut, yakni menuju kepada agama Allah serta menjalankan segala ajaran syari'atnya. Maksud dari fitrah itu ialah Tauhidullah. Sabda NabiShallallahu 'alaihi wa Sallam,

"Tidaklah yang dilahirkan (ke dunia) itu kecuali dilahirkan atas fitrah. Maka kedua orang tuanya lah yang menjadikannya Yahudi, Nasrani, atau Majusi.

Adapun yang dimaksud dengan fitrah di atas adalah Agama Tauhid, yakni Islam . Maka merupakan hal yang tidak wajar bagi setiap insan pada masa kini apabila mereka tidak mengikuti fitrahnya untuk beragama Tauhid itu lantaran pengaruh lingkungan. Karena Allah sendiri telah megaskan hal ini di dalam hadits qudsi. Sebagaimana yang diriwayatkan Rasulullah Shallallahu 'alaihi wa Sallam,

“..Dan sungguh Aku telah ciptakan hambaKu seluruhnya dalam keadaan hanif (lurus dalam tauhid). Dan sungguh telah datang pada mereka syetan-syetan yang menjadikan mereka keluar dari agama mereka."

${ }^{5}$ Ibid, Vol 4 h. 368

${ }^{16}$ Ibid, vol 12 h. 50

${ }^{17}$ Ibid, Vol 6 h. 27

${ }^{18} \mathrm{Abu}$ ja'far Muhammad bin Jarir at-Thabari, Tafsir at- Thabari, Kairo : Maktabah Tauqifiyah, jilid 8, h.148

${ }^{19}$ Ibid, h. 367

${ }^{20}$ Muttafaq 'alaih, hadits dari Abu Hurairah. Lihat Irwa' a-lGhalil, 1220.
Dalam ayat ini Allah menerangkan hidayah kepada nabi Adam dengan dalil -dalil kauniyah, setelah menerangkan tentang metode para rasul dan kitab-kitab dengan mengatakan wahai nabi berilah peringatan kepada manusia ketika Tuhanmu mengeluarkan dari tulang rusuk nabi Adam dan keturunan mereka dari masa ke masa. Kemudian dilanjutkan dengan dalil -dali keberadaan Tuhan dan keesaan Tuhan. ${ }^{23}$

Menurut Quraish Syihab dalam ayat ini diterangkan bahwa apabila kita termenung bertafakur dan membebaskan segala hal ihwal yang menyebabkan segala kesibukan maka akan terdengarlah suara hati nurani yang mengajak untuk berdialog, mendekat bahkan menyatu dengan suatu totalitas wujud yang maha mutlak. Suara itu mengantar untuk menyadarkan betapa lemahnya manusia di hadapanNya,dan betapa kuasa dan perkasa dia yang maha Agung itu. Suara yang didengar itu adalah suara fitrah manusia. Setiap orang memiliki fitrah itu, dan terbawa serta olehnya sejak kelahiran walau sering kali karena kesibukan dan dosa-dosa ia terabaikan dan suaranya begitu lemah sehingga tidak terdengar lagi, tetapi bila diusahakan kan untuk didengarkan, Kemudian benar- benar tertancap di dalam jiwa, maka akan hilanglah segala ketergantungan kepada unsur - unsur lain kecuali kepada Allah semata. ${ }^{24}$

Sedangkan menurut Yusuf Qardlawi ayat ini ini fitrah manusia yang salim yang didapat langsung dari tuhanNya yang kadang luput jika manusia itu dalam keaadaan senang dan sebaliknyamanusiaseringingatkalaudalamkeadaansempit $^{25}$

Dalam tafsir at Thabari Fitrahdiungkap dalam hadits dengan berbagai bentuk dan makn, masing-masing hadits memiliki topik dan latar belakang yang berbeda-beda. Hadits pertama"Seseorang tidak dilahirkan kecuali dalam keadaan fitrah,maka kedua orang tuanya yang menjadikannya Yahudi, Nasrani, atau Ma- 
jusi." (H.R. Al-Bukhari dan Muslim dari Abu Hurairah)Hadits kedua :"Sepuluh macam yang termasuk dalam kategori fitrah, yaitu (1) mencukur kumis, (2) membiarkan jengggot panjang dan lebat, (3) bersikat gigi/bersiwak, (4) menghirup air untuk membersihkan hidung, (5) menggunting kuku, (6) membersihkan jarijemari, (7) mencabut bulu ketiak, (8) mencukur bulu kelamin, (9) membersihkan kencing dengan air, dan (10) berkumur-kumur." (H.R. Muslim dan Abu Dawud dari Aisyah)Hadits ketiga:"Zakat fitrah itu diwajibkan sebanyak segantang kurma atau segantang gandum bagi setiap orang Muslim merdeka maupun budak, laki-laki maupun wanita." (H.R. Al-Bukhari dari Ibn Umar) Hadits keempat: "Shalat Idul Adha itu sebanyak dua rakaat, shalat Idul Fitri itu sebanyak dua rakaat, shalat orang yang berpergian itu sebanyak dua rakaat, shalat Jumat itu sebanyak dua rakaat." (H.R. Al-Nasa'i dari Umar ibn al-Khattab)

Hadits kelima :"Doa Nabi SAW: Ya Allah yang menciptakan langit dan bumi, yang mengetahui yang gaib dan yang tampak, Tuhan segala sesuatu dan sesuatu itu menjadi milik-Nya. Aku bersaksi bahwa tiada tuhan selain Engkau. Aku minta perlindungan-Mu dari keburukan hawa nafsu dan syaitan serta kroni-kroninya." (H.R. AlDarimiy dari Abu Hurairah) ${ }^{26}$

Masih menurut al-Qurtubi yang mengambil beberapa pendapat diantaranya az-Zujaj dan at-Thabari yang dimaksud fitrah Allah adalah mengikuti agama allah yang dicipatakan untu manusia sesuai perintah Allah dalam surat adzDzariat ayat 65 dan surat al isra ayat 7 , surat arrum ayat 43 yang dimaksud adalah Din al islam

${ }^{21}$ Sebagaimana dalam riwayat lain dikatakan bahwa yang dimaksud fitrahitu ialah "hadzihi alMillah".

${ }^{22} \mathrm{HR}$. Muslim, Ahmad dari hadits 'Iyadh bin Himar. Lihat Syarh 'Aqidah ath-Thahawiyah, Ibn al-'Izz, (Beirut: al-Maktab alIslami 2006), h. 16

${ }^{23}$ Jumhuriyah misra al-arabiyah wizarat al-auqaf al-Majlis al-a'la liSyuuni al Islamiyah, Al Muntakhab fi tafsir al -Quran al karim,Kairo : cet,19, h.234-235

${ }^{24} \mathrm{M}$ Quraish Shihab, Wawasan al-Quran,tafsir tematik atas pelbagai persoalan umat,Jakarta : Mizan, 2013, cet, 2, h. 20

${ }^{25}$ Yusuf Qardlawi, al-Iman wa-al hayat, Kairo: Maktabah wahbah, 1996, cet, 10 , h. 24 dan harus menghadapkan wajah sepenuh hati agar sesuai dengan yang dimaksud oleh syariat (agama). ${ }^{27}$

Menurut penulis fitrah dalam hal ini selain kemabali kepada Tuhan, ia juga berjalan sesuai dengan syariat Allah, sebagaimana dalam surat ar -Rum bahwa kalau itu sudah diyakini kebenaranya maka berjalanlah lurus tidak usah melencenng menengok kiri dan kanan yang akan menyaebabkan tidak sampai kepada tujuan semula yaitu berpegang teguh kepada syariat, dan kembali kepada fitrah yaitu Allah, karena pada fitrahnya manusia pasti berasal, menuju dan kembali kepada Allah.Selanjutnya dalam surat al-jatsiah Quraish shihab menafsirkan bahwa mereka yang tidak mempercayai wujud Tuhan adalah orang-orang yang kehabisan akal dan keras kepala ketika berhadapan dengan satu kenyataan yang tidak sesuai dengan nafsu kotornya yang demikian dari ayat menguraikan diskusi antara nabi Ibrahim dengan raja namrud ( QS. al-baqarah : 258 ) atau Musa ketika berhadapan dengan Firaun salah satu bukti bahwa pernyataan ini lahir dari keras kepala adalah pengakuan Fir'aun sendiri ketika ruhnya akan meninggalkan jasadnya. Dalam konteks ini, alQuran menjelaskan sikap Firaun yang ketika itu kembali kepada Fitrah, namun sayang dia telah terlambat. Hal ini sebagaimana dijelaskan dalam surat Yunus ayat 90-91. ${ }^{28}$

Ayat ini sekaligus membuktikan bahwa kehadiran Tuhan merupakan fitrah manusia yang merupakan kebutuhan hidupnya. Kalaupun ada yang mengingkari wujud tersbut, maka pengingkaran tersebut bersifat sementara. Dalam arti bahwa pada akhirnya, sebelum jiwanya berpisah dengan jasadnya ia akan mengakuiNya. Memang kebutuhan manusia bertingkat -tingkat ada yang harus dipenuhi segera seperti kebutuhan kepada udara, ada yang dapat ditangguhkan beberapa saat seperti air minum. Kebutuhan pada makan dapat ditinggalkan lebih lama daripada kebu- 
tuhan minuman, tetapi kebutuhan pemenuhan seksual bisa lebih lama ditangguhkan dari pada kebutuhan kepada makan dan minum demikian seterusnya. Kebutuhan yang paling lama dapat ditangguhkan adalah kebutuhan keyakinan akan adanya allah SWT. $^{29}$

Dalam surat ar- Ra'd At-thabari menafsirkan ayat 28 ini dengan beberapa hadis seperti yang diriwayatkan oleh Basyar dari Qatadah وتطمئن قلوبهم بذكر اله ia mengatakan tenang dan tentram ini sesuai dengan firman Allah dengan demikian hatinya orang-orang mukmin adalah sahabat Rasulullah SAW.Begitu pula dengan yang diriwayatkanoleh Husein bin muhammaddari Mujahid ia mengatakan الا بذكراله تطمئن القلوب sama saja dengan yang diriwayatkan oleh Mutsana dari Mujahid $^{30}$ Menurut penulis ini artinya manusia tidak mendapat sebuah ketentraman jiwa yang hakiki tanpa berzikir kepada Allah, kalupun ada orang yang kelihatannya tentram damai, itu hanya nisbi dan bersifat sementara.

\section{Kesimpulan}

Setelah memaparkan beberapa ayat tentang fitrah manusia : Keyakinan tentang keesaan Allah maka penulis dapat menyimpulkan bahwa kata fitrah dengan kata Allah adalah dua kata yang tidak bisa dipisahkan, karena fitrah itu adalah asal kejadian, kembali ke asal, bahkan dikatakan juga artinya Tuhan, manusia itu pada dasarnya memang ada unsur Tuhan maka di mana pun dia berada ia tidak akan bisa lepas dengan Allah. Sedangkan Tuhan itu sebenarnya Allah untuk siapa pun hanya saja ketika orang belum bisa mengakui bahwa Tuhan itu Allah karena faktor pengetahuan dan hidayah yang belum sampai. Selanjutnya berdasarkan para mufassir menge-

${ }^{26} \mathrm{Abu}$ Abdullah Muhammad bin ahmad al-anshari al-Qurtubi, Tafsir al- Qurtubi Tahqiq salim Musthafa al- Badri, Beirut Dar al kutub alilmiyah h. 17-22.

${ }^{27} \mathrm{Ibid}$

${ }^{28} \mathrm{M}$ Quraish Shihab, opcit h. 23

${ }^{29}$ Ibid nai ayat-ayat yang berhubungan dengan Tuhan menyimpulkan bahwa kembali kepada fithrah artinya juga berpegang teguh kepada agama Allah, hidup berprilaku sesuai dengan yang disyari'atkan oleh agama. Pada fitrahnya semua manusia mengakui bahwa ia butuh kepada Allah sebagai mana butuhnya terhadap udara, makan minum. Hanya manusia yang keras kepala saja yang tidak mengakui bahwa dia itu butuh kepada Tuhan yang maha tinggi, maha sempurna, zat yang memang pantas untuk disemabah dan dijadikan tempat kembali.

\section{Daftar Pustaka}

al-Ashfahaniy, Al-Raghib.2004. Mu'jam Mufradat Alfaz Al-Quran. Beirut:Dar al Fikr. 1872. Mu'jam Mufradat Alfazh al-Quran. Beirut:Dar al-Fikr.

al-Aqad Abbas Mahmud. 1994.Allah, Kairo : Dar al-Nahdlah,

al-Jurjaniy, Syarif Ali ibn Muhammad. 1988. Kitab al-Ta' rifat. Beirut:Dar al-Kutub al-Ilmiyah.

Jumhuriyah misra al-arabiyah wizarat al-auqaf al-Majlis al-a'la liSyuuni al Islamiyah, Al Muntakhab fi tafsir al -Quran al karim,Kairo : cet,19,

al-Bukhari, Imam. Shahih al-Bukhari. Semarang: Thaha Putra.

al-Darimiy, Ibn Muhammad 'Abd Allah. Sunan al-Darimiy. Beirut:Dar al-Fikr.

Fairuz Abady, Qamus al-Muhith, Birut : Dar al fikr

al-Husain, Abu al-Baqa' Ayyub ibn Musa.1992. Al-Kulliyah; Mu'jam fi al-Mushthalah

Ma'luf ,Luis. 195 al-munjid fi al-Lughah, Beirut : al-mathba'ah al-katsulikiyah th 1956

Muhammad fuad Abdul baqi, Mu'jam mufahras li -alfazh al- Quran, Indonesia : Maktabah dahlan

al-Maraghiy, Musthafa. Tafsir al-Maraghiy.

${ }^{30}$ Opcit, at-Thabari h. 149 
Libanon:Dar al-Ahya'

al-Nasa'I, Imam.1930. Sunan al-Nasa'I. Beirut:Dar al-Fikr.

Al-Qurthubiy Abu ja'far Muhammad bin Jarir atThabari, Tafsir at- Thabari, Kairo : Maktabah Tauqifiyah, jilid 8

al-Raziy, Muhammad Fahr al-Din. Tafsir Fahr al-Raziy al-Masyhur bi al-Tafsir Mafatih alGhaib. Beirut:Dar al-Fikr.

al-Shafa, Ikhwan. 1957. Rasail Ikhwan al-Shafa wa Khalan al-Wafa. Beirut:Dar Sadir.

Faidh Allah, Ilm Zadah. Fath al-Rahman li Thalab Ayat al-Quran. Indonesia:Maktabah Dahlan. Al-Qurthubiy Abu ja'far Muhammad bin Jarir atThabari2005. Tafsir at- Thabari. Kairo : Maktabah Tauqifiyah, jilid 8
Tim Redaksi, Kamus Besar Bahasa Indonesia, Jakarta: Pusat Bahasa Departemen Pendidikan Nasional Balai Pustaka, th.2000

Mujib, Abdul. 1999. Fitrah dan Kepribadian Islam. Jakarta:Darul Falah.

Muslim, Imam.1981. Shahih Muslim bi Syarh Imam al-Nawawiy. Beirut:Dar al-Fikr.

Qardlawi Yusuf.1996. al-Iman wa-al hayat, Kairo: Maktabah wahbah, 1996

Rahman, Munawwwar. 1995. Kontekstual Doktrin Islam dalam Sejarah. Jakarta:Paramadina.

Sa'ad, Al-Thablawiy Mahmud.1984. Al-Tashawwuf fiy Taras ibn Taimiyat. Mesir:al-Hai'at alMishriyyat al-'Ammat li al-Kitab.

Shihab, M. Quraish. 1996. Wawasan Al-Quran, Tafsir Maudhu'I atas Perbagai Persoalan Umat. 